\title{
THE RELIGIOUS LIFE OF THE PERSIANS
}

To understand the real religious life of a people it is not sufficient to study merely their theological books or to take the biographies of a few leading spirits. The first show what their religious life ought to be; the latter, what it may become in its highest form. In this paper we are seeking to understand the religious life and attitude of the great bulk of the Persian Shiahs as exemplified in their lives.

The first thing which strikes us is the exalted position ascribed to the family of the prophet rather than to the prophet himself. Mohammed, according to tradition, is largely responsible for this, for he is reported to have said that he will intercede only for those who believe in the family of Ali. Naturally the Persians have exalted the latter and his descendants to a transcendent position in their hopes for the future life. Leaving out the clause, " and he was God," most of them would have no hesitancy in repeating the first two verses of John's Gospel with Ali's name for "the Word." It is commonly said "Ali is not God but he is not separate from God." A tradition, the mere repeating or hearing of which is a great work of merit, is that of the Mantle. Mohammed was lying under his mantle one day when his grandchildren appeared. He called them to him under the mantle; then their father, Ali, came in and was called to lie under the mantle; finally his daughter Fatimah joined them. At that juncture Gabriel appeared and asked God who these were. To this the reply came: "These are the father of Fatimah, the husband of Fatimah and the children of Fatimah; for the sake of these five I created all that I have created."

In a modern treatise called "Concise Information," among other things we read that Mohammed said, "God created my light and the light of Ali befort He created the world and Adam and for 500,000 years we were busy with praising God before there was anything else to praise Him. When God determined to create the universe 
He uncovered my light and created the throne and its pedestal, and by God, I am better than the throne and its pedestal; then $\mathrm{He}$ uncovered the light of Ali and created the Pen and the Tablet, and by God, Ali is better than the Pen and the Tablet; next, He uncovered the light of my son, Hasan, and created the seven heavens and the angels, and by God, Hasan is better than the seven heavens and all the angels; then He uncovered the light of Husayn and created from it Paradise and the Houris, and by God, Husayn is better than Paradise and the Houris. Lastly God created darkness which covered the seven heavens and the angels (in fear) began to praise God and call upon Him and asked me to intercede; God spoke a word and created a great light like a chandelier in the midst of the heaven to light them; and that light is the light of my daughter Fatimah."

Doubtless there were thoughful Persian Mohammedans in all ages who did not accept such tales, but to-day they are still universally believed by the mass of common people and result in a practical deification, not only of the first five of the family of Mohammed, but also of their descendants. Imam Riza who died a martyr (as they believed), in Khorasan has become almost the patron saint of Persia under ægis of these others. Hazrat-iAbbas who was killed in the battle of Kerbela, is a great miracle worker, feared above all others. An oath in his name is one of the most binding in the whole category because of the fact of his miracle-working power for good or evil. All through the country there are numerous shrines built over the graves of descendants of Mohammed some of which are great centres of pilgrimage and many are reputed to have more or less power to work miracles of healing. Many take their sick a long way to lay them in some shrine.

In its origin, this devotion was largely partisan and to-day the fateful battle of Kerbela forms the centre around which their devotional thought swings. We do not need to dwell upon the historical features of that battle; it is the traditional accounts as accepted by the Persians which have value for their religious life. Accord- 
ing to this, Hussain, the grandson of Mohammed and true Caliph, was promised his rights if he would visit Kufa. Setting out with his family and a small party of followers, seventy all told, he found too late that he had been betrayed. The governor had discovered the plot and given orders to stop him; Hur refused to attack the family of the prophet and joined their little band at the last moment, but Shimr had no such scruples. Even then the latter's followers made a weak attack upon the sacred family but cut off the party from water. The Persians consider it a sin to kill a mere animal while it is thirsty but for three days the Imam and his family were kept from water while little children cried from thirst. Even there Abbas, Hussain's half-brother, was the great wonder-working warrior. After his right arm had been cut away he fought on with his left and when that was gone he seized his sword in his teeth and still fought. A stray arrow struck Hussain in the mouth and soon the little band of warriors was killed and the women and children, descendants of the prophet, were carried away into captivity. A wave of dismay must have spread throughout the Moslem world for the descendants of the prophet were lying dead, killed by the faction which had most opposed him during his life.

The story and its commemoration in one way or another form the centre and core of the religious life of the mass of Persians, and if such an expression may be used in this connection, afford their chief entertainment. Wild spirits will find amusement in drinking, gaming, and dancing; in such places there are circles for literary or political discussion; some cheap mountebank troops furnish amusement in the streets for the poor; but, aside from births and weddings, the only entertainment open to the devout Shiah is some presentation of this story. The only theatrical performances worthy of the name in the country are presentations of the Passion Play of Hussain and Hasan. Such presentations have some religious value as works of merit but do not rank as high in this regard nor fill the part in their lives as other forms of presentation do. 
The most common presentations are recitations by rosa khans in meetings called rosa khanis. These are in vogue at all times but especially on the eve of. Friday and during the months of mourning, Moharram and Safar. In some particular these rosa khanis have the value of masses in the Roman Church: after a death in the family they are usually held for the benefit of the dead; frequently a man in making his will arranges for so many rosa khanis as further works of merit for his soul or leaves endowments for this purpose. To bear the expense of such meetings during life is a great work of merit. Rich men commonly arrange for them regularly in their own houses on certain days of the week throughout the year. Well-known ecclesiastics hold them in their own houses, drawing a crowd in proportion to their ability and reputation for sanctity. In the latter case the reciter acts as host, and serves tea but expects a present in money or kind from his patrons.

Naturally a large class of men make their living by giving such recitals. It requires a good memory and a fine voice. There are a few women, otherwise not generally of good repute, who act as rosa khans but as a rule women attend meetings for women only or have a secluded place in the gatherings for men.

The manner of the meetings themselves is simple. The leader sits upon a chair or special pulpit and recites stories of the prophets. In the only one I have had opportunity of attending (for foreigners are not very welcome), there were two reciters; one, the regular incumbent who had come by arrangement and probably had a fixed annual allowance; the other was an itinerant who had dropped in for the evening in the hope of a present. The latter led off with some routine story of the saints in which he felt most proficient. The audience was somewhat moved but not to excess. The former, however, adapted his story to the situation by telling tales of unbelievers who had been converted by miracles of the saints which were revealed to them. (When $\mathrm{I}$ was in Khorasan a rosa lihan confessed his inability to argue religion with me but assured me that if $I$ would perform the 
ceremonial ablutions, wrap myself in the usual white grave clothes and breathe a prayer to Imam Riza in the shadow of whose shrine we sat, he would reveal himself to me in such a way that I could not but believe. These stories were on much the same order.) The second man interspersed his story with exhortations to think upon the sufferings of the holy saints and had much greater influence upon his hearers who, from long habit, were expecting to be moved by his performance. I fear I gave some offense because I was not more moved.

A skillful leader can work his audience up to almost any pitch. The meetings are danger places especially during the month of Moharram when all religious feeling runs high. A popular leader plays upon his audience by story and exhortation, adding here and there a denunciation of this or that, or a little sermon. The crowd may break out into violence for which they will later be sorry. Not many years ago in such a meeting in Resht a missionary and a recent convert were denounced. The matter was belittled by many in the community but resulted in so much petty persecution and threats of violence to the convert that he had to leave the city soon after. During the last few years Moharram has been an anxious time to the political leaders and the government lest these gatherings be used for political purposes in one way or another.

The anniversary of the death of Hussain comes on the tenth of Moharram while that of Hasan falls near the end of the following month so that these two months are months of mourning. When in the rotation of the lunar year, the vernal equinox, the great spring feast of the Persians, falls within the months of mourning, all its celebrations are omitted. The people ordinarily wear black throughout these months and avoid all large festivities.

Early in the month of Moharram the people begin to practice for the characteristic processions which are known as "dastahs." Each quarter or sub-quarter has its own procession, and other groups, such as the merchants from a certain city, arrange their own. One of the former kings divided the cities into two factions be- 
tween which there grew up much rivalry resulting in many quarrels and even pitched battles in which blood was often shed. Even now quarrels are frequent between processions; and this, together with the cloak which is sometimes made of these expressions of fanaticism to foment rebellions, makes these days an anxious time for the government. Recently it has been the custom to detail armed police to accompany each procession to prevent quarrels and bloodshed. That these precautions are not unnecessary was illustrated in Resht a few years ago, when, in the midst of high political tension, a quarrel between two processions resulted in the death of two men; while, under the cloak of this excitement, plans for a revolution were perfected which resulted in the death of the Governor-and ultimately in the deposition of the king.

These "dastahs" are a combination of pageant and funeral procession. The pageant feature represents the bloody scenes following the battle: riderless horses, children being carried away captive, savage conquerors strutting along, and the weeping widowed women. As the impressionable East watches these scenes, the ancient tragedy lives again for them and they are moved to sobbing and tears. It is a great work of merit to throw water to the children as they march calling as of old " $I$ thirst, I thirst." In the funeral features are to be reckoned numerous banners: the standard of Mohammed, the standard of Hazrat-i-Abbas, consisting of a severed arm and hand, and many others, including one of a long, thin piece of metal which because of its vibrations, is said to be weeping. Then come the bands of mourners: children beating on pieces of wood, bands of older men chanting and throwing dust upon themselves or beating their heads in a mild way, and bands of younger men furiously beating their breasts with their hands or their backs with bunches of chains. On the tenth, if the political situation is favorable, these processions pass in review before the governor.

A special feature reserved for the tenth day of the month is bands of devotees who cut their heads as they march. 
This is a comparatively new custom and the story of its origin illustrates the Persian attitude and the way such customs grow. About sixty years ago a rosa khan in Kerbala appeared in the rosa khani with a large sword in his hand. As he drew near to the close of his recitation he exclaimed, "On this day the blessed Hussain had a bloody forehead. Shall I not have one also?" and suiting action to words he began to cut his head with his sword. The following year a few others followed his example and now throughout the whole of Persia are thousands who take part each year in this exercise of extreme devotion. Some of them are pure fanatics who do it to win merit; others have vowed during illness of themselves or some dear one to take part in these processions or perhaps a mother has dedicated her son in this service of the Imams.

A few years ago when it was deemed inadvisable to hold a general review I witnessed the organization of such a procession. In this particular group was a man whose special "stunt" was to run large pins or nails into his body from which he hung various objects of more or less weight, and who then carried a platform of lamps which seemed, at least, to be supported on the nails run into his body. While he was preparing others were gathering. Each, having shielded his head, carried a short sword about two feet long and now donned white grave clothes to signify that he was ready to go to death in the service of the Imam. When all were ready, each took his neighbor's sash in his left hand and, sword in his right, began to march around in a circle, shouting, "Hasan, Hussain," in time to his steps; encouraged by the onlookers they all began to beat time with their swords. Gradually one, then another began to strike his head with the edge of his sword until the blood flowed. As enthusiasm arose, the chant became quicker and the band of men set out marching in this fashion to a shrine and mosque not far away. As we followed after we found one poor fellow had fallen down in a faint from the loss of blood. Later in the day these devotees are entertained by various men of the city. 
On another occasion I was permitted to witness the review from a seat near the reviewing stand. It was a remarkable sight; the long processions, each with its own special features and its bands of mourners beating themselves and calling to mind the sufferings of the Imams, the waving banners, the weeping people, the blaring trumphets. Then followed a pause. From the distance the measured chant, "Hasan, Hussain," of the sword men. Their slashing knives appeared above the heads of the crowd, then their blood-stained white garments; the air became electrical and the excitement intense as they approached the governor's place. It was indeed a wild scene. One band refused to pass on. They had demanded a certain prisoner from the governor. The latter refused. Their shouts rose with renewed persistence while their swords were brandished in the air to emphasize their demands. It was the old picture of the mob demanding the present of a life on the feast day and the unwilling governor. Again the mob won.

The Persians say that even a foreigner cannot listen to the story of Kerbela without being moved. It is not the distant historical tale, so very real to them, though dim and unreal to him, that moves him; it is the evidence of the reality of this tale to the easy-going pleasure loving Persian and the effect upon him, that moves the onlooker to sympathy. What is it that transforms a quiet business man into an enthusiast willingly cutting his head and shouting, "Hasan Hussain?" The scornful may mock, as did Elijah of old, but the man of love can only marvel and pity.

The question arises, What is the religious value and significance of this devotion to the family of Ali? Why has it such a hold upon the people? We must not fail to recognize the elements which form practically a substitute for an incarnation as we would understand it. The Shiah formally denounces the Christian deification of Christ but the Persian has always been given to seeking such incarnations, and Persia's religious history is studded with characters who have claimes to be manifestations of the Divine Being, culminating in the Babi Bahai 
movement of our own day. The theological position of Islam has been too strong for them but into the very heart of Shiah Islam we find these equivalents. The Persian desires a closer relation to the Unseen, a greater confidence that his prayers will be heard, a fuller assurance of heaven than the cold hard dogma of the Koran and the theologians.

A second apparently close approach to Christianity is found in the idea of an atonement through the death of Hussain. In traditions and the passion play Mohammed is made to say that Hussain will die for his people. Many assert that the death of Hussain holds the same place in the Shiah faith that that of Christ does in the Christian. This proposition is popularly held in Persia. It may be that this doctrine has been emphasized and developed in the effort to refute Christianity's exclusive claims to an atoning Saviour. It certainly makes it difficult for the missionary in Persia to preach Christ crucified in a public way, for so many of his hearers simply scorn this idea since, in their opinion, the death of Christ is of little value as compared with the death of Hussain. Christ has only five wounds while Hussain, according to tradition, had one thousand nine hundred and fifty-one and hence is a much more worthy sacrifice.

On a closer examination, however, we find an important difference. Although the word "sacrifice" is sometimes used in regard to Hussain, the Persian theologian never uses the word "atonement" in respect to the work of Hussain but always "intercession." Hussain saves by his intercession, not through a vicarious death as we understand the death of Christ. Tradition has been piled upon tradition to emphasize this feature and exalt the family of the prophet. Mohammed said he would not intercede for any one who did not believe in Ali and his children. One day when fondling Hussain, Mohammed told of his coming martyrdom and said that whoever visits his tomb acquires the merit of one greater and one lesser pilgrimage to Mecca. To the protest of Ayesha (who is jealous of the family of Fatimah) he replies that it will not be the merit of only two such pilgrimages but 
of ninety, and so on until she gives it up. Ali's family are more powerful intercessors than Mohammed because they suffered so much more than he. He had only a broken tooth but Ali was stabbed, Hasan poisoned, Hussain slain in battle, Fatimah had a miscarriage because of rough usage, another child was slain at Kerbela, etc. Hussain stands pre-eminent because of his greater suffering (there are traditions to show that this was voluntary for he might have had the assistance of innumerable jinns if he had asked it) but in the last day Fatimah will really be the great intercessor for she will bring to the judgment the proofs, as it were, of their right to intercede: Mohammed's broken tooth, Ali's turban, Hasan's liver, Hussain's bloody shirt, Abbas's arms, the blood of the innocent child and her own stillborn babe. When God sees these proofs of their suffering $\mathrm{He}$ will not refuse their pleas. Their influence will be exerted to bring into Paradise all who have caused people to cry by reciting the sufferings of the prophet's family, all who have cried at hearing the tale, and even those who have pretended to cry!

Although such traditions would apparently assure each Shiah a certain and easy way of entering Paradise, the Persian really looks upon these various acts of devotion as a means of piling up merit which in the last day will balance his misdeeds. They consider the moral sins, lying, stealing, adultery, even drinking of liquor as comparatively venial, easily offset by works of merit. This is the reason why such devotional exercises overshadow so greatly in the thought of the people, the regular prescribed religious duties. A man who observes the times of prayer, for instance, merely does his duty and acquires merit only negatively as it were. Whereas if he has failed in some point he can atone for the omission by some work of supererogation. Thus the real question becomes "How can I acquire merit?" There are many ways of acquiring merit but the greatest value is attached to acts of devotion toward the family of the prophet. Thus, a pilgrimage to some shrine (if important enough) is better than supporting a hospital for the poor, and a 
gift to a descendant of the prophet is of more value than to an ordinary man even though the former be well-to-do and the latter in dire need.

In passing we may note another approach to a Christian doctrine. We commonly think of the resurrection as our proof that Christ lives and makes intercession, but the Shiah has not needed any such proof to lead him to a similar faith and confidence in the living reality of his Imams. Not only does he think that all the Imams are now living in Paradise (their bodies never decay) but that the twelfth Imam never died but is still alive, the Lord of Time, though hidden from men's eyes, and that he will appear again to reign and rule upon earth.

The Christian missionary is confronted therefore with a difficult and peculiar situation. On the one side, there is the historically bitter verbal opposition to the doctrine of the incarnation but a virtual acceptance of the same in regard to Ali and his family. On the other hand, their failure to distinguish between the significance of the death of Christ and that of Hussain obscures the wide underlying difference. Even the sinlessness of Christ does not appeal to the Persian at first, for, to him, all prophets are sinless. The only doctrine which he will readily acknowledge as distinctly Christian is that of the indwelling of the Holy Spirit. His Imam may occasionally help him but they do not dwell in him. The greatest hindrance, therefore, to the progress of Christianity in Persia is the absence of evidence of such an indwelling in those nominal Christians with whom the Persians are most familiar and the chief hope of reaching them is through a Spirit-filled life in their midst which will ultimately convict them of sin and show them a higher, more beautiful ideal than any they have heretofore known.
Resht, Persia.
J. Davidson Frame, M.D. 